\title{
A CLINICO-PATHOLOGICAL STUDY OF 163 UNTREATED CASES OF CHRONIC HEPATITIS C
}

\author{
Joachim Graf, Kan Toriyama and Hideyo Itakura
}

\begin{abstract}
We performed a clinico-pathological study of 163 untreated cases of chronic hepatitis C. Eighty five percent of the patients were clinically asymptomatic and their physical examinations shoued unremarkable or minimal changes at the time of the liver biopsy Liver function tests tended to present slight abnormalities, involning mild elevations of the activity of the aminotransferases and gamma-glutamil transferase levels. In spite of these mild abnormalities, advanced chronic liter disease was bistologically detected in eighty nine percent of the patients, mainly showing chronic actile bepatitis. 7 he most characteristic bistological finding uas an interlobular bile duct damage. wbicb correlated with the presence of lymphoid aggregates in the portal tracts and with the development of fibrosis.
\end{abstract}

Key-words: Chronic bepatitis C. Bile duct damage Lymphoid aggregate. Histopatbology.

Recently the genome of the blood-borne non-A, non-B virus, designated hepatitis $C$ virus ( $\mathrm{HCV}$ ), has been cloned and specific assays have been developed to detect antiHCV antibodies ${ }^{2}$. Since the introduction of routine blood screening for hepatitis $B$ surface antigen (HBsAg), the incidence of hepatits B virus infection has decreased and hepatitis $C$ has been the major cause of posttransfusional hepatitis. The clinical presentation of chronic hepatitis $C$ as reported in the literature suggests that the disease often runs a silent course, with few symptoms and signs. and mild biochemical abnormalities ${ }^{1011}$. Nonetheless, severe liver damage have been reported to occur with high frequency 11 is it. The aim of this study is to report the results of the clinical, biochemical and histopathological examinations of 163 untreated cases of chronic hepatitis $\mathrm{C}$, analyse the correlations and relationships among these findings and discuss the nature of chronic hepatitis $C$.

\section{MATERIAL AND METHODS}

We reviewed the clinical data and histological specimens from 1991 through 1994

\footnotetext{
Department of Pathology, Institute of Tropical Medicine, Nagasaki University, Sakamoto 1-12-4, Nagasaki, Japan. Supported by JICA (Japan International Cooperation Agency).

Address for correspondence. Dr. Joachim Graf. Al Julia da Costa, 1945/102 - Bigorrilho, 80730-070, Curitiba, Paraná, Brazil. Fax 225-41-92

Recebido para publicação em 10/02/95
}

pertaining to 163 untreated patients with chronic hepatitis $C$ in the Deparment of Pathology, Institute of Tropical Medicine, Nagasaki University. The main reason for the biopsy procedure was to evaluate chronic alterations of serum aminotransferases levels and to have a histological diagnosis in serologically defined cases of hepatitis C. From 224 cases initially recorded, 61 were excludec: on the basis of the presence of positive testing for HBsAg. presence of hepalocellular carcinoma, previous treatment with interferon. evidence of autoimmune hepatitis or alcoholic liver damage.

The sera from the patients was assayed for the presence of $\mathrm{HBSAg}$ and anti-C. $100(-3 \mathrm{HC})$ using a radiommunoassay kit (Dainabol. Japan and Ohtsuka assay (co. L.d. Japan. respectively). Sera negative for both $I B B \times A g$ and anti-C100-3 HCV was retested using a second generation assay which detects in addition to C,100-3 antigen also the (,22-3 and C33-c antigen by radiommunoassay (Othsukat assay Co. LTD., Japan). Additional case's of $\mathrm{HCV}$ infection included those positive sera for HCV-RNA as detected by the polymerase chan: reaction technique.

The liver biopsy specimens were fixed in buffered formalin, embedded in paraftin and stained with hematoxylin and cosin. AzanMallory and silver impregnation for reticulin fiber. All biopsy specimens were classified according to the type of chronic hepatitis. using conventional criteria, as having chronic persistent hepatitis (CPH), chronic active 
Graf J, Toriyama K, Itakura H. A clinico-patbological study of 163 untreated cases of chronic bepatitis $C$. Rerista da Sociedade Brasileira de Medicina Tropical 29:21-25, jan-fev, 1996.

hepatitis (CAH) with mild or moderate degree of inflammation and with or without cirrhosis. The specimens were graded with respect to the degree of piecemeal necrosis, portal and lobular inflammation and fibrosis according to the histological activity index (HAI) scoring system designed by Knodell et al". Any evidence of the presence of piecemeal necrosis was sufficient to rule out $\mathrm{CPH}$, and to categorize the biopsy as, at least, mild CAH. Cirrhosis was diagnosed when the presence of bridging fibrosis and nodule formation could be established.

The presence or absence of the following histological findings were registered for each biopsy; bile duct damage and bile duct proliferation. plasma cell infiltration in portal tracts, acidophilic bodies, sinusoidal lining cell ativation, fatty metamorphosis and dysplasia of hepatocyles. Bile duct damage was considered present when the following features were observed alone or in combination; multilayered or stratified epithelium with swollen epithelial cells, inflammatory cell infiltration in epithelium, vacuolization of epithelial cells, loss of polarity and degeneration of epithelial cells.

The statistical significance of the results was evaluated by the Chi-square test. A p-value < 0.05 was considered significant.

\section{RESULTS}

Clinical characteristics. Table 1 presents demographic data of the 163 patients with chronic hepatitis $\mathrm{C}$. The mean age of the patients was 54 years and the male to female ratio was $2: 1$. Most of the patients $(70 \%)$ were between 50 and 70 years old. Thirty nine out of 105 males $(38 \%)$ and 24 out of $58(41 \%)$ females had a history of blood transfusion.

Table 1-Demographic data and bleod transfusions in patients ath chrmic heprititis $C^{\circ}$

\begin{tabular}{lccc} 
& Number & Mean age (mean/range) & Blood Transfusion \\
Male & 105 & $54(24-72)$ & $38 \%$ \\
Female & 58 & $55(27-75)$ & $41 \%$ \\
\hline Total & 163 & $54(24-75)$ & $85 \%$ \\
\hline
\end{tabular}

Eighty five percent of the patients were asymptomatic at the time they were submitted to liver biopsy, and the most frequent symptom was general fatigue (11\%) followed by vague abdominal discomfort (3\%) and itching (1\%). Sixty percent presented no abnormalities at the physical examination and $36 \%$ presented hepatomegaly, while only $2 \%$ had splenomegaly, and $2 \%$ hepatosplenomegaly. Among the patients with hepatomegaly, there was a male predominance $(43 / 105 ; 41 \%)$ when compared to the female group $(15 / 58 ; 25 \%)$, and this trend occurred more frequently in the age groups older than 50 years. No statistical significance could be established between either age and gender, and any biochemical abnormalities or histological finding, nor between clinical complaints and abnormal physical finding, and any biochemical abnormalities or histological findings.

Biochemical Findings. The biochemical abnormalities concerning the aminotransferases and gamma-glutamiltranspeptidase tended to be mild. The mean levels, and ranges of AST, ALT and GGT observed were 61UI/1(13-421), 77IU/1(15-358) and 63IU/I(11-241), respectively and no correlation could be established among any biochemical determination and specific histological findings.

Histological Findings. The general histological findings in chronic hepatitis $\mathrm{C}$ are indicated in Table 2. A hepatitis-associated bile duct damage, first described by ChristoffersenPoulsen $^{8}$, is shown in Figure 1. The lesion depicted is of the type 2 hepatitis-associated bile duct damage and was seen in $57 \%$ of the patients. Bile ductular proliferation was observed in $47 \%$ of the patients. Lymphoid follicle formations with or without germinal center in portal tracts (Figure 2) were seen in $42 \%$ of the patients. The majority of the cases $(85 \%)$ showed mild degree of piecemeal necrosis. Fatty metamorphosis of the

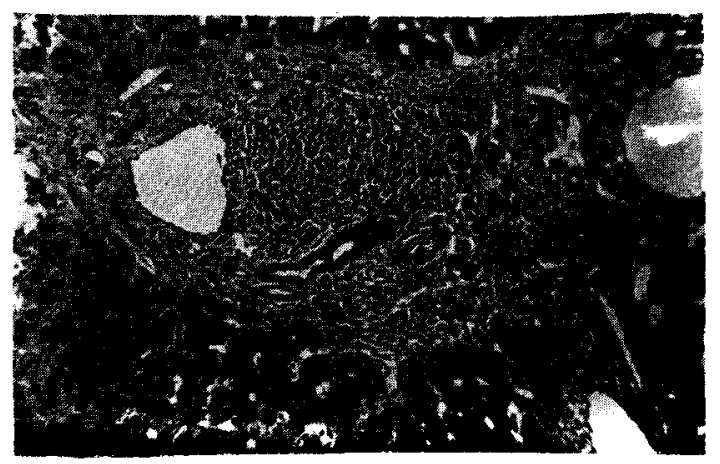

Figure 1. Interlobular bile duct lesion in ibrom bepatitis $C$ 
Graf J, Toriyama K, Itakura H. A clinico-patbological study of 163 untreated cases of chronic bepatitis $C$. Revista da Sociedade Brasileira de Medicina Tropical 29:21-25, jan-fev, 1996.

Tabie 2 - General histological findings in chronic befatitis C:

\begin{tabular}{lc}
\hline Portal Tract Lesion & 10 \\
Lymphoid Infiltrate & $3(63)(\% / 1)$ \\
none & $92(56)$ \\
loose condensation & $62(38)$ \\
lymphoid follicle without germinal center & $6(4)$ \\
lymphoid follicle with germinal center & $11(7)$ \\
Piecemeal Necrosis & $139(85)$ \\
none & $12(8)$ \\
mild & $1(1)$ \\
moderate & $93(57)$ \\
marked & $68(47)$ \\
Bile Duct Damage & $48(29)$ \\
Bile Ductular Proliferation & $149(91)$ \\
Plasma Cell Infiltration & $158(97)$ \\
Parenchymal Lesion & $50(31)$ \\
Sinusoidal lining cell activation & $47(29)$ \\
Spotty necrosis & $16(10)$ \\
Acidophilic bodies & \\
Fatty metamorphosis & $9(6)$ \\
Dysplasia of hepatocytes & $60(37)$ \\
Fibrosis & $74(45)$ \\
Limited in portal tract & $20(12)$ \\
Portal fibrous expansion &
\end{tabular}

hepatocytes was detected in $29 \%$ of all the cases. Most cases presented more advanced fibrosis, as in the cases of fibrous portal expansion and bridging fibrosis.

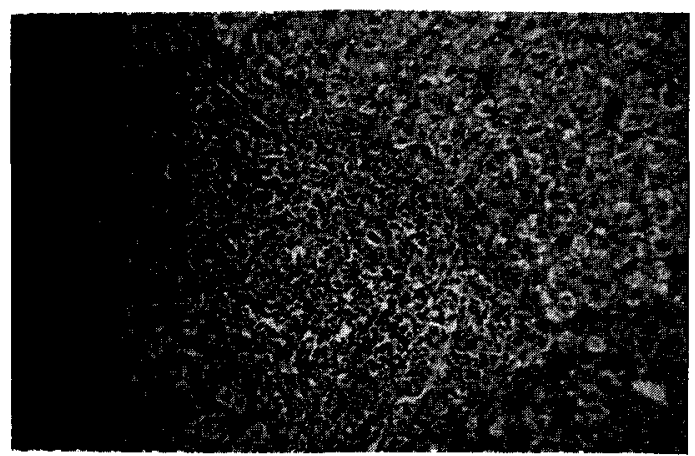

Figure 2. Lymphoid follicle in portal tract in cbronic bepatitis $C$.

Table 3 relates the bile duct damage to portal inflammation in chronic hepatitis $\mathrm{C}$. Bile duct damage significantly correlated with the degree of portal inflammation and especially all cases of lymphoid aggregates with germinal center in portal tracts showed bile duct damage $(p<0.05)$.

The correlation between bile duct damage and the degree of fibrosis is indicated in Table
4. Bile duct damage significantly correlated with advanced fibrosis $(p<0.05)$.

Table 3 - Bile duct danage (BDD) and lymphoid infiltrate in portal tract

\begin{tabular}{|c|c|c|}
\hline \multirow[t]{2}{*}{ Lymphoid infiltate } & \multicolumn{2}{|c|}{ [SDD } \\
\hline & presint & alsent \\
\hline None $(n=3)$ & $1(33 \%)$ & $2(67 \%$ \\
\hline Loose condensation $(n=92)$ & $12(46 \%)$ & $50(54 \%)$ \\
\hline Follicle without germinal center $(n=62)$ & $44(71 \%)$ & $18(26) / 1 / 4)$ \\
\hline Follicle with germinal center $(n=6)$ & $6(100 \%)$ & (1) $\left(()^{\prime \prime / / h}\right)^{*}$ \\
\hline
\end{tabular}

Table 4 - Bile dact damage (BDD) and fibrosts.

\begin{tabular}{lcc}
\hline \multicolumn{1}{c}{ Fibrosis } & Present & didsent \\
\hline Limited to portal tract $(\mathrm{n}=9)$ & $3(33 \%)$ & $6(67 \%)^{*}$ \\
Portal fibrous expansion $(\mathrm{n}=60)$ & $36(36 \%)$ & $24(40 \%)^{*}$ \\
Bridging fibrosis $(\mathrm{n}=74)$ & $50(68 \%)$ & $24(32 \%)^{*}$ \\
Cirrhosis $(\mathrm{n}=20)$ & $15(75 \%)$ & $5(25 \%)$ \\
\hline
\end{tabular}

* Statistically significant, $p<0.05$.

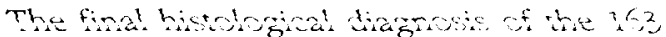
cases of hepatitis C included 19 (12\%) of chronic persistent hepatitis, $113(69 \%)$ cases of chronic active hepatitis (CAH), with mild activity and without cirrhosis, 16 (10\%) cases of CAH with mild activity and with cirrhosis, $15(9 \%)$ cases of CAH wiht moderate activity and without cirrhosis, and $1(1 \%)$ case with CAH with moderate activity and with cirrhosis. 
Graf.J. Toriyama $K$, Itakura $H$. A clinico-patbological study of 163 untreated cases of chronic bepatitis $C$. Retista da Sociedade Brasileina de Medicina Tropical 29:21-25, jan-fev, 1996.

\section{DISCUSSION}

The results of our study confirm the general impression that chronic hepatitis $C$ runs a protracted course with few nonspecific symptoms and signs, along with mild biochemical abnormalities, despite the presence of, or progression to, advanced chronic liver disease. The majority of the patients were asymptomatic at the time of diagnosis, and were referred for liver biopsy to elucidate chronic serum elevation of aminotransferases or to provide histological information for further interferon therapy. Physical examination was unremarkable in most of the patients. When present, the most common physical abnormality was hepatomegaly, more prevalent among older male patients. It has been reported that older patients present more severe manifestations of the disease ${ }^{1 / 2}$. Among the biochemical tests, abnormalities involved mainly serum levels of AST, ALT and GGT, but no correlation could be established with the degree of piecemeal necrosis or portal or intralobular inflammation. This lack of correlation with hepatic histology has already been pointed out ${ }^{1011}$ and could be a result of sampling error due to the fluctuating course of aminotransferases and advanced fibrosis. In this regard, the clinical severity cannot be assessed by the serum aminotransferases level alone, and liver biopsy is essential in assessing the extend of liver damage. Fluctuation in aminotransferase levels may represent alteration in viral replication, host immunity, or both" ${ }^{\prime \prime}$. These fluctuant levels correlate to episodes of lobular necrosis, thought to be responsible for the progression to chronic disease ${ }^{15}$.

The most conspicuous histological finding in our study was bile duct damage (BDD), observed in $57 \%$ of the cases, while the incidence rates in the literature differs from $22 \%^{15}, 25 \% \%^{15}, 30 \%, 31 \%{ }^{8}, 90 \% \%^{3}$ to $91 \% \%^{3}$. The affected bile ducts are small or medium sized interlobular ducts. The BDD appears to involve imunological mediated reaction to antigens on bile duct epithelium, possibly histocompatibility antigens (HLA) or HLA antigens displayed with virus-related

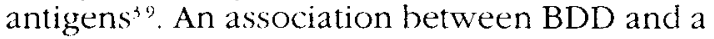
better response to interferon therapy in patients with chronic hepatitis $\mathrm{C}$ has been documented and may be of prognostic significance".
The occurrence of BDD had a significant correlation with the degree of portal/periportal inflammation in our cases. The affected bile ducts were usually surrounded by a dense lymphoid infiltrate, sometimes with a germinal center, close to the damaged duct. Lymphoid follicles have been reported to occur in frequencies varying from $49 \% \%^{19}, 52 \% \%^{8}, 63 \%^{13}$ to $78 \% 0^{1}$. In our study, $42 \%$ of the patients displayed lymphoid follicles and among these $73 \%$ had BDD. Lymphoid follicle is a feature of a variety of chronic inflammatory diseases, often of autoimmune nature and their presence in hepatitis $\mathrm{C}$ may reflect an ongoing immunologic reaction. Lymphoid follicles may be formed early in the acute stages of hepatitis: The appearance or disappearance of lymphoid follicles during the course of the illness does not seem to correlate with either improvement or deterioration of the histological activity index ${ }^{12}$.

A significant correlation between the occurrence of BDD and the degree of hepatic fibrosis in non-cirrhotic livers, which has been described in several reports ${ }^{17}$ could also be detected in our cases. While $60 \%$ of the cases presenting fibrous portal expansion and $68 \%$ of those with bridging fibrosis displayed bile duct damage, only $33 \%$ of the cases involving limited fibrosis in the portal tracts showed BDD.

In conclusion, chronic hepatitis $\mathrm{C}$ is a relentlessly chronic progressive disease, frequently running a silent course, with mild or unremarkable biochemical abnormalities, which do not correlate with the histological activity of this disease. Liver biopsy is the only method to assess the degree of liver damage. The single most characteristic histological feature of chronic hepatitis $\mathrm{C}$ is a bile duct damage, surrounded by a lymphoid aggregate.

\section{RESUMO}

Realizou-se estudo clinico-patológico de 163 casos não tratados de bepatite crônica C. A maioria dos pacientes era clinticamente assintomática e seus exames fisicos demonstratam alteraçöes inespecificas ou minimas por ocasião da biópsia bepática. As provas de função bepática tendiam a apresentar alteraçoes discretas, envolvendo especialmente os niveis séricos das aminotransferases e gama-glutamil transpeptidase. Apesar destas alterações discretas, detectou-se doença bepática crônica bistologicamente avançada, 
Graf J, Toriyama K, Itakura H. A clinico-pathological study of 163 untreated cases of cbronic bepatitis C. Revista da Sociedade Brasileira de Medicina Tropical 29:21-25, jan-fel, 1996.

consistindo principalmente de bepatite crônica ativa. O acbado bistológico mais caracteristico foi lesão de ducto biliar interlobular, que se correlacionou com a presença de agregados linfóides nos tratos portais e com o desemolvimento de fibrose.

Palavras-chaves: Hepatite crônica C. Lesão de ducto biliar. Agregado linfóide. Histopatologia.

\section{ACKNOWLEDGMENTS}

The first author was sponsored by Japan International Cooperation Agency (JICA) under the program of 'Training Course in Research for Tropical Medicine.

\section{REFERENCES}

1. Bach N, Thung SN, Schaffner F. The histological features of chronic hepatitis $\mathrm{C}$ and autoimmune chronic hepatitis;a comparative analysis Hepatology 15:572-577, 1992.

2. Choo QL, Kuo G, Weiner AG, Overby LR, Bradley DW, Houghton $M$. Isolation of a cDNA clone derived from a blood borne non-A, non-B viral hepatitis genome. Science 224:359- 362, 1989.

3. Danque POV, Bach N, Shaffner F. HLA-DR expression in bile ducts in hepatitis C. Modern Pathology 6:327-332, 1993

4. Elloway RS, Gordon SC, Long JC. Histologic features of hepatitis $C$ related to mode of viral transmission; comparision of blood transfusion vs intravenous drug use. Gastroenterology 102(suppl):A25, 1992.

5. Healy CJ, Chapman RWG, Flemming KA. Normal versus abnormal liver transaminases in hepatitis C infection; comparision with histology.Journal of Pathology173(suppl):156A, 1994.

6. Knodell RG, Ishak KG, Black WC, Chen TS, Craig R, Kaplowitz N, Kierman TW, Wollman J. Formulation and application of a numerical scoring system for assessing histological activity in asymptomatic chronic active hepatitis. Hepatology 1:431-435, 1981

7. Kuo G, Choo QL,Alter HJ, Gitnick GI, Redeker AG, Purcell RH, Myamura T, Dienstag JL, Alter MJ, Stevens CE ,Tegtmeier GE.An assay for circulating antibodies to a major etiologic virus for human non-A, non-B hepatitis. Science 244:362-364, 1989.
8. Lefkowitch JH, Apfelbaum TF. Characterization of liver biopsy pathology. Journal of Clinical Gastroenterology 11:225-232, 1989.

9. Lefkowitch JH, Shiff ER, Davis GL, Perrilo RP, Lindsay K, Bodenheimer, Jr HC, Balart LA, Ortego TJ, Payne J, Dienstag JL, Gibas A, Jacobson IM, Tamburro CH, Carey W, O'brien C, Sampliner R, Van Thiel DH, Feit D, Albrecht J, Meschievitz C, Sanghvi B, Vaughan RD, The Hepatitis International Therapy Group. Pathological diagnosis of chronic hepatitis $\mathrm{C}$; a multicenter comparative study with chronic hepatitis $B$. Gastroenterology 104:594-603, 1993.

10. Merican I, Sherlock S, McIntyre N, Dusheiko GM. Clinical, biochemical and histological features in 102 patients with chronic hepatitis $\mathrm{C}$ virus infection. Quarterly Journal of Medicine 86:119$125,1993$.

11. Patel A, Sherlock S, Dusheiko GM, Scheuer PG, Ellis LA, Ashrafzadeh P. Clinical course and histological correlation in post-transfusion hepatitis C. the Royal Free Hospital experience. European Journal of Gastroenterology \& Hepatology 3:491-495, 1991.

12. Poulsen H, Christoffersen P. Abnormal bile duct epithelium in liver biopsies with histological signs of viral hepatitis. Acta Pathologica Microbiologica Scandinava 76:383-390, 1969.

13. Robberts JM, Searle JW, Cooksley WGE. Histological patterns of prolonged hepatitis $C$ infection. Gastroenterologia Japonica 28(suppl 5):37-41, 1993.

14. Scheuer PJ. Classification of chronic viral hepatitis; a need for reassessment. Journal of Hepatology 13:372-374, 1991.

15. Scheuer PJ, Ashrafzadeh P, Sherlock S, Brown D, Dusheiko GM. The pathology of hepatitis C. Hepatology, 15:567-571, 1992.

16. Schmid M, Pirovino M,Altorfer G, Gudat F, Bianchi L. Acute hepatitis non-A, non-B; are there any specific light microscopic features? Liver 2:61-67, 1982.

17. Vyberg $M$. The hepatitis-associated bile duct lesion. Liver 13:289-301, 1993. 